\title{
TEATER ANTARA KREATIVITAS, DINAMIKA KELOMPOK, KEMATANGAN PSIKOLOGIS, DAN PEMBELAJARANNYA DI SEKOLAH DASAR
}

\author{
Yunus Abidin
}

\begin{abstract}
ABSTRAK
Teater dapat dipandang dalam berbagai dimensi. Dimensi pertama adalah bahwa teater merupakan wujud kreativitas para pelakunya. Dalam pembentukan proses kreatif tersebut teater mencerminkan dinamika kelompok para pelakunya. Lebih jauh teater dapat pula dikatakan sebagai wadah pengembangan kematangan psikologis.

Sejalan dengan hal di atas, teater merupakan materi pembelajaran di sekolah karena dinggap memilki banyak muatan posotif di dalamnya. Teater dalam pembelajaran membuat sebuah kontribusi yang penting terhadap perkembangan anak. Teater menyangkut bahasa, persepsi, perkembangan konsep, pengetahuan estetik dan pada akhirnya keseluruhan barisan pengalaman itu sendiri. Teater lebih jauh merupakan seni bahasa dan kemampuan berkomunikasi yang dapat digabungkan dalam beberapa cara yang menyenangkan dan untuk tujuan yang bervariasi dimulai dari mempertinggi perkembangan bahasa dan kosa kata sampai kepada kemampuan pemahaman menggunakannya dan membaca kritis.
\end{abstract}

\section{Kata Kunci : Teater, Kreativitas. Dinamika Kelompok, Psikologis, dan Pembelajaran}

\section{A. Teater dalam Dimensi Kreativitas}

Istilah teater barangkali bukanlah istilah asing baik dalam dunia seni maupun dalam dunia pendidikan. Dalam dunia seni, teater dikenal sebagai sebuah pementasan fenomena hidup dan kehidupan manusia di atas panggung guna memberikan pencerahan batin bagi sejumlah penonton. Teater juga dikenal dengan istilah media untuk membebaskan ekspresi di atas pentas. Lebih jauh, teater juga dikenal sebagai seni kolektif yaitu seni yang memadukan berbagai ragam seni lain: seni suara, seni musik, seni tari, seni dekorasi, seni tata busana, seni tata cahaya dan berbagai jenis seni lain yang relevan.

Sebagaimana layaknya ragam seni yang lain, teater mengutamakan peran pentingnya sebagai wahana berkreativitas. Bentuk kreativitas yang ditekankan dalam 
teater terutama adalah kreativitas berekspresi melalui media gerak/akting. Oleh karena itu, berbagai sastrawan mengistilahkan teater sebagai permainan untuk pembebasan ekspresi. Istilah ini muncul sebagai pencerminan bahwa teater adalah wahana yang membebaskan pemain untuk melakukan berbagai peniruan terhadap kelompok tertentu dan unsur budayanya, yang selama ini dianggap melanggar batasbatas konvensi sosial, norma, dan moral tertentu. Dalam teater, pemain bebas berekspresi menjadi siapa pun dan menjadi “seperti apa” pun.

Sebagai bentuk kreativitas, teater harus didukung (pasti didukung) individuindividu yang kreatif. Individu yang kreatif adalah individu yang memiliki ciri berpikir orisinalitas, fleksibilitas, kelancaran, dan elaborasi. Selain itu, individu kreatif adalah individu yang terbuka, luwes, bebas mengekspresikan diri, memiliki kemampuan apresiasi yang tinggi, berminat terhadap kegiatan kreatif, percaya diri, dan mandiri.

Tahap awal proses teater adalah proses penciptaan gagasan yang dilakukan oleh individu yang terlibat di dalamnya. Dalam teater setiap individu diberikan kebebasan untuk mengemukakan gagasan berkenaan dengan pementasan yang akan dilakukannya baik dalam penentuan tema, lakon, dan berbagai rencana lain. Hal ini menunjukkan bahwa teater bukan hanya membutuhkan kemampuan berakting tetapi lebih jauh kemampuan berpikir kritis dan cerdas. Teater bukanlah penjara bagi individu yang ada di dalamnya. Teater adalah rumah yang menyenangkan sebab setiap individu diberikan kebebasan untuk bersikap dan berperilaku dalam hal menentukan langkah dalam pengembangan organisasinya dengan tetap taat terhadap norma yang ada di dalamnya. Oleh sebab itu, teater pada dasarnya membina kemampuan berpikir seseorang agar fleksibel dan lancar namun tetap memperhatikan elaborasi dari berbagai pikiran yang dikemukakan dari masing-masing individu.

Selain membina kemampuan berpikir, teater sebagai bentuk wadah kreativitas juga membentuk individu yang terbuka artinya individu yang mau menerima terhadap perubahan, kritik, dan arahan dari berbagai pihak. Individu dalam teater adalah individu yang luwes dan mampu masuk dimensi manapun. Hal ini terbukti bahwa 
wadah teater bukan hanya terdapat dalam lingkungan seni tetapi juga dalam lingkungan pendidikan. Hal lain yang penting bahwa teater adalah tempat bagi individu yang mau mengekspresikan dirinya, membina kemampuan apresiasi, menggeluti kegiatan kreatif sehingga individu ini memiliki rasa percaya diri dan mandiri.

\section{B. Teater dalam Dimensi Dinamika Kelompok}

Sebagai seni kolektif teater tidak akan hidup tanpa keterlibatan personal di dalamnya. Berdasarkan kenyataan ini, teater merupakan salah satu bentuk dinamika kelompok. Dinamika kelompok dapat diartikan sebagai proses pertumbuhan, perkembangan, dan perubahan dalam suatu kelompok tertentu. Kelompok adalah kumpulan individu yang memiliki hubungan dan ketergantungan guna mencapai tujuan tertentu. Hubungan dalam sebuah kelompok akan terbentuk bila ada solidaritas, rasa memiliki, ketergantungan, dan kesadaran akan tugas dan tanggung jawab dalam hal pencapaian tujuan kelompok. Dengan demikian teater secara langsung maupun tidak langsung selalu membina individu dalam hal solidaritas, rasa memiliki, saling ketergantungan, dan tanggung jawab.

Sekait dengan penyataan di atas, teater tidak akan berjalan tanpa adanya individu-individu di dalamnya. Keberadaan individu ini harus pula terhubung dalam solidaritas yang tinggi. Sekait dengan pengertian bahwa teater adalah seni kolektif maka sangat tidak mungkin akan terbentuk sebuah pementasan yang berhasil tanpa adanya solidaritas antarindividu dalam teater. Hal lain yang penting untuk keberhasilan pementasan teater harus pula ditumbuhkan rasa memiliki pada setiap individu dalam kelompok. Dengan memiliki rasa ini akan terpupuk rasa tanggung jawab pada setiap individu untuk terus memainkan perannya dalam kelompok. Dengan kesadaran bahwa teater adalah kerja kolektif maka akan tumbuh pula bahwa tanggung jawab dalam teater harus pula diiringi rasa ketergantungan pada individu lain yang memiliki tugas tanggung jawab yang berbeda. 


\section{Teater dalam Dimensi Kematangan Psikologis}

Sejalan dengan perkembangan ilmu pengetahuan, proses penjabaran kemampuan mental manusia semakin berkembang. Hal ini dibuktikan dengan munculnya berbagai istilah seperti halnya IQ, EQ dan lahirlah istilah CQ (Creativity Question). CQ merupakan suatu indikator untuk menilai tingkat kreativitas seseorang yang meliputi komponen: rasa ingin tahu, keluwesan, produktivitas, keterbukaan, keyakinan visi, intuisi, kemampuan menyederhanakan masalah, pengambilan risiko, kepekaan, ketertarikan terhadap tantangan, ketertarikan terhadap petualangan, dan kemampuan memecahkan masalah. Berdasarkan konsep CQ di atas, teater sebagai wadah kegiatan kreativitas akan menggiring individu untuk dapat memenuhi komponen CQ di atas. Jika individu yang kreatif dalam teater telah mampu memiliki beberapa saja komponen di atas, penulis berkesimpulan bahwa teater bukan hanya terkait dengan ekspresi tetapi lebih jauh pembinaan kematangan psikologis seseorang.

Adanya kesamaan konsep teater ditinjau dari segi kreativitas dan dinamika kelompok akhirnya menggiring kita pada suatu simpulan bahwa berteater adalah proses pematangan psikologis. Jika dibandingkan dengan konsep psikodrama yang menyatakan bahwa berperan adalah persiapan untuk hidup, pencerahan batiniah, merekapitulasi makna kehidupan, dan menyatakan reaksi emosional dan sosial dapat ditarik benang merah bahwa berteater adalah proses mempersiapkan individu untuk memerankan perannya dalam kehidupan sekaligus memberikan pencerahan bagi arah kehidupannya.

Berdasarkan konsep di atas, sangat jelas tergambar bahwa individu harus mampu membina kematangan psikologisnya agar mampu berperan dalam masyarakat. Kematangan psikologis ini meliputi kematangan dalam hal kepribadian, kecakapan, dan perilaku berinteraksi. Kematangan dalam kepribadian dapat meliputi berbagai hal antara lain tanggung jawab, disiplin, percaya diri, sikap, perasaan, emosi, dan cinta. Semua komponen ini tercermin dalam kegiatan teater. Tanggung jawab dan disiplin misalnya, tanpa asas ini pementasan tidak akan dapat dilaksanakan. Semua unsur pementasan dari pemain hingga penonton memiliki tanggung jawab tertentu 
yang harus diembannya. Ketidakhadiran satu orang pemain saja maka pementasan akan gagal dilaksanakan. Bermain teater adalah melatih rasa percaya diri, berlatih sikap serta berlatih mengendalikan perasaan dan emosi. Tanpa kematangan unsur ini anggota teater tidak akan mungkin mampu membawakan peran secara optimal di atas panggung. Demikian pula unsur pendukung yang lain.

Kecerdasan, kecakapan emosional, kecakapan menyederhanakan dan memecahkan masalah, kecakapan mempertimbangkan risiko merupakan bentuk kematangan dalam hal kecakapan. Proses berteater juga pada dasarnya adalah proses pembinaan kecakapan. Penyelenggaraan pementasan teater memerlukan kecerdasan pemain dalam membedah naskah, menghayati dan memerankan tokoh cerita. Lebih jauh kematangan menyederhanakan dan memecahkan masalah serta kecakapan mempertimbangkan risiko yang dihadapi jelas merupakan bagian kegiatan keseharian anggota teater dari mulai penggarapan naskah, penentuan pementasan hingga pelaksanaan pentas serta evaluasi pentas.

Kematangan dalam hal perilaku interaksi meliputi kematangan dalam hal keluwesan, keterbukaan, dan motivasi berinteraksi. Seluruh aspek ini mutlak ada dalam teater. Anggota teater harus mampu memerankan peran secara baik, terbuka atas arahan dan perubahan, serta termotivasi untuk selalu berinteraksi secara luwes dalam kelompok maupun dengan pihak di luar kelompok. Tanpa adanya interaksi antarkelompok maupun intrakelompok teater hanya sekadar wadah mati dan beku. Jadi, jika dikaitkan dengan pandangan teater dari segi kreativitas maupun dari segi dinamika kelompok maka tugas-tugas perkembangan kepribadian ini sudah tergambar jelas dalam teater.

\section{Teater dalam Dimensi Pembelajaran di Sekolah Dasar}

Teater dapat pula dimaknai dari segi dunia pendidikan. Pendidikan menurut Undang-Undang Nomor 20 tahun 2003 merupakan usaha sadar untuk mewujudkan suasana belajar dan proses pembelajaran agar peserta didik secara aktif mengembangkan potensi dirinya untuk memiliki kekuatan spiritual keagamaan, 
pengendalian diri, kepribadian, kecerdasan, akhlak mulai, serta keterampilan yang diperlukan dirinya, masyarakat, bangsa dan negara. Sejalan dengan konsep pendidikan ini maka teater dapat pula dikatakan sebagai suatu proses pendidikan. Dalam teater, individu telah digali potensi untuk memiliki kematangan psikologis guna mempersiapkan keberadaannya dalam suatu masyarakat. Berdasarkan kenyataan ini berteater adalah proses mendidik seseorang agar matang secara lahiriah maupun jasmaniah.

Makna teater dalam lingkup pendidikan yang lebih kecil yaitu proses pembelajaran juga dapat dirasakan. Teater sebagai bentuk performasi dari naskah drama jelas memiliki keterkaitan yang jelas dengan mata pelajaran Bahasa dan Sastra Indonesia. Bahkan untuk jenjang SD kompetensi siswa dalam mementaskan teater menjadi salah satu standar kompetensi yang dipersyaratkan dalam Kurikulum. Sebagai indikator ketercapaian standar kompetensi ini adalah bahwa siswa harus mampu memahami pengetahuan tentang pementasan teater meliputi bloking, moving, akting, monolog, casting, properti, improvisasi, dan epilog. Dari segi sikap siswa harus mampu memiliki sikap tanggung jawab, jujur, dan keseimbangan emosi. Dari segi keterampilan siswa diharapkan mampu memainkan peran, penyutradaraan, dan daya kreativitas. Keseluruhan kompetensi ini sudah dengan barang tentu menjadi bagian utama dalam teater. Dengan demikian jika siswa telah aktif dalam kegiatan teater secara otomatis ketiga ragam indikator ini akan mampu dicapai siswa.

Selain memiliki keterkaitan secara khusus dengan kemampuan bersastra, teater juga memiliki peran untuk meningkatkan kemampuan siswa adalah kebahasaan baik dalam hal menyimak, membaca, menulis, maupun berbicara. Dalam lingkup yang lebih luas kemampuan dasar berteater merupakan model pembelajaran interaktif yang dapat diterapkan dalam kelas yang dikenal dengan istilah model bermain peran dan sosiodrama. Menyikapi hal ini teater memiliki makna ganda bagi pembelajaran bahasa dan sastra Indonesia.

Mengapa pembelajaran teater dilaksanakan di sekolah dasar? Asosiasi Teater Anak menjelaskan tujuan dari teater sebagai berikut: “Teater dapat digunakan untuk 
mengajarkan seni drama dan/atau memotivasi dan memperluas pembelajaran di dalam bidang isi yang lainnya. Partisipasi dalam teater mempunyai kekuatan untuk mengembangkan bahasa dan komunikasi, membangun gerak hati manusia untuk memerankan tanggapan dunia yang layak untuk memahaminya. teater membutuhkan pikiran yang berdasarkan logika dan intuisi, membuat pengetahuan, dan menghasilkan kesenangan estetik.

Bagaimana melaksanakan pembelajaran teater di sekolah dasar? Teater dapat disajikan dengan beberapa cara dan disesuaikan untuk beberapa tingkatan umur dan pengaturan instrukksional. Ini merupakan perpaduan latihan perasaaan dan pantomime serta improvisasi.

\section{Latihan Perasaan}

Aktivitas pelatihan perasaan membantu individu menjadi sadar akan perasaan mereka dan mendorong kreativitas dan kepercayaan diri mereka melalui uungkapan kesadaran. Kuncinya adalah kemampuan berkonsentrasi, anak mengembangkan seperti mereka berkomunikasi melalui nonverbal dengan cara ekspresi wajah, gerak tubuh dan gerakan. Guru harus menekankan penciptaan kepercayaan diri dan antusiasme untuk ekspresi drama. Aktivitas latihan perasaan dapat dikembangkan sebagai latihan pemanasan untuk membantu anak memperkembangkan darai gerakan yang sederhana ke bentuk yang lebih sulit dari drama.

Dengan anak kecil, aktivitas latihan perasaan dapat dikembangkan dengan permainan mereka yang spontan. Guru harus meneliti apa yang anak mainkan selama periode tidak terstruktur dalam permainaan drama dan membangun saat ini untuk membawa anak ke dalam drama. Dengan anak yang lebih tinggi, latihan perasaan harus dimulai dengan yang lambat untuk memberikan mereka kepercayaaan diri dalam kemampuan mereka untuk menggunakan tubuhnya untuk mengungkapkan perasaan dan ide serta untuk menggunakan beberapa bentuk bahasa melalui teater. Anak yang lebih tinggi juga akan mengembangkan kesadaran terhadap dirinya sendiri sebagai individu seperti kepekaan terhadap orang lain dalam peristiwa berkomunikasi. 
Dibawah ini beberapa ide untuk memfokuskan aktivitas pemanasan dalam empat indera.

a. Sentuhan

Guru harus meminta siswa duduk di lantai, setiap individu melakukan aktivitasnya sendiri. Lampu yang redup dapat membantu menciptakan suasana aman. Guru harus memberikan petunjuk sebagai berikut (satu aktivitas dalam satu waktu):

1) “Terdapat balon di atas lantai di depan kalian. Ambillah. Pompalah. Ikatkan di ujungnya dan sematkan tali. Biarkan ia mengapung di udara seperti yang kalian lihat.”

2) “Terdapat makhluk kecil meringkuk di belakang kalian. Ini menakutkan. Ambillah. Timanglah dan buat ia nyaman.”

3) "Terdapat segumpal pita perekat, tanah liat di depan kalian. Ambillah. Buatlah sesuatu dari benda tersebut.”

b. Pengecapan

Untuk aktivitas ini, anak harus bekerja dalam kelompok, menatap satu sama lain. Guru harus meminta kepada satu pasangan untuk menebak dengan tepat apa yang orang lain pura-pura makan :

1) "Buatlah roti lapis kesukaanmu dan makanlah."

2) "Makanlah makanan kesukaaanmu."

3) "Makanlah sesuatu yang tidak kamu sukai."

c. Penglihatan

Siswa harus kumpul dalam kelompok kecil dan duduk melingkar, setiap orang menatap satu sama lain. Guru harus mengatakan kepada mereka bahwa terdapat koleksi sesuatu di tengah-tengah lingkaran; kemudian berkeliling lingkaranlah, setiap individu harus membawa satu jenis dan berpantomim apa yang telah dia pilih. Seteleh setiap orang selesai, mereka harus menebak apa yang dilakukan yang lain. Di bawah ini beberapa idenya: 
1) “Terdapat sebuah peti penuh dengan pakaian di tengah-tengah lingkaran. Ambillah satu dari peti tersebut, dan cobalah. Hanya terdapat satu benda dalam peti.”

2) “Terdapat tumpukan bungkusan hadiah di dalam kotak di tengah-tengah lingkaran. Pilih salah satu, bukalah, dan ambil keluar dan gunakan.”

3) "Mainan kesukaan anda di tengah-tengah lingkaran. Ambillah dan tunjukkan bagaimana anda memainkan permainan itu.”

d. Suara

Untuk aktivitas ini, anak harus berdiri di kelompok kecil (lagi membentuk lingkaran kecil). Dalam menanggapai petunjuk guru, setiap orang harus menggambarkan bagaimana suara teliti membuat perasaannya. Setelah setiap orang selesai, siswa harus mencoba menceritakan apa yang lain lakukan. Dibawah ini beberapa idenya:

1) "Saya akan membuat suara. (pukullah meja dengan tekanan ritmik). Bermainlah apa yang membuat kamu berikir.”

2) “Berikan petunjuk yang sama, akan tetapi gosokkan tangan bersama-sama untuk membuat suara merayap.”

3) "Berikan petunjuk yang sama, akan tetapi buatlah suara goresan dengan sebuah benda yang berlawanan di papan tulis.”

2. Pantomim dan Improvisasi

Pantomim dan Imprivisasi merupakan perluasan yang alami dari latihan perasaan dan dapat juga mengikuti dari penelitian guru dalam permainan anak secara spontan. Pantomim menggunakan ekspresi wajah, gerakan tubuh dan gerak badan untuk berkomunikasi sebagai pengganti suara dan kata, dan improvisasi menambah cara bicara/logat terhadapt gerakan dan aksi yang spontan. Teknik drama ini dapat peranan penting terhadap permainan adegan yang lebih rumit, dramatisasi cerita, atau penulisan naskah. 
Guru harus menyimpan catatan ide-ide untuk memotivasi aktivitas pantomime dihubungkan terhadap pengalaman siswa, sastra atau bidang isi lainnya. Beberapa topic difokuskan yaitu:

a. Hewan: gerakan, interaksi antara anak dengan hewan peliharaan, interaksi diantara hewan dan sebagainya.

b. Permainan: olahraga, permainan, mainan, dan tempat menyenangkan untuk dikunjungi.

c. Sastra Abak: sajak, pisi, buku bergambar, dongeng rakyat, dan cerita.

d. Lintas Kurikulum: Ilmu social, Ilmu pengetahuan, matematika, dan seni.

Guru dapat juga menggunakan kostum dan alat-alt pentas lain untuk memotivasi pantomime siswa (contoh., topi, mantel tanpa lengan, tongkat, ember, keranjang). Demikian juga, musik memberikan sumber motivasi yang bagus.

Selain penerapan dalam bentuk aksi di atas, teater dapat pula dilakukan dengan pembacaan naskah. Peserta membaca dan menafsirkan daftar bacaan dengan nyaring dari naskah dirubah terutama untuk setting ini. Naskah dapat dari beberapa tipe teks daftar bacaan dari buku bergambar untuk anak kecil dan novel untuk anak yang lebih besar; cerita rakyat dan dongeng serta tipe-tipe daftar bacaan tradisional yang lain (contohny fable, dongeng dan legenda); sajak dan lagu-lagu; cerita dan puisi dari pembaca bunga rampai dan dasar, dan bahkan non fiksi. Dalam menyampaikan teater dengan cara membaca naskah, anak memegang naskah yang dapat dibaca atau dilihat sekilas dalam menampilkan pembaca. Tidak ada kostum khusus, set, alat-alat, pencahayaan atau musik yang dibutuhkan. Jadi satu kali naskah telah dikembangkan, teater dapat dilakukan dan ditampilkan hampir seketika di dalam kelas.

Penilaian dalam pembelajaran teater merupakan proses yang terus-menerus bagi guru dan anak. Aspek signifikan yang lain dalam penilaian teater yaitu guru, sebagai pengevaluasi merupakan contoh perilaku yang positif yang terus-menerus bagi diri anak dan penilaian kelompok. Apa yang guru katakan dan bagaimana dia 
mengatakannya akan mempengaruhi bagaimana siswa menilai dan merencanakan dengan yang lainnya.

Beberapa tipe penilaian disediakan bagi pembelajaran teater di SD, diantaranya sebagai berikut.

1. Catatan bermain teater, guru harus meneliti dan mengambil bagian catatan selama beberapa tipe dari sesi teater untuk memberikan dasar bagi tindak lanjut diskusi. Penelitian atas perubahan tingkah laku anak, kata dorongan, dan pujian serta pertanyaan dan saran harus semua dicatat untuk digunakan selama konferensi.

2. Tanya jawab isi teater: tanya jawab merupakan bagian kritis dari setiap tipe sesi teater. Tanya jawab merupakan sifat dasar untuk merencanakan sesi teater berikutnya. Tipe pertanyaan untuk memulai diskusi ini meliputi:

a. Apa yang kamu sukai dari yang telah kamu lihat?

b. Apa yang kamu nikmati selama menonton?

c. Siapa yang kamu perhatikan melakukan sesuatu hal dengan baik (atau minat, penuh daya khayal, berbeda, humoris)?

d. Kenapa kamu menyukai dia?

e. Apa yang kita butuhkan untuk ke depannya? Bagaimana kita melakukannya?

f. Apa yang harus kita konsentrasikan ke depannya? (Ide-ide: konsentrasi, kerjasama, gerakan, langkah, energi, karakter, dialog, suara, gaya tubuh, menggunakan ruang).

Sebagai penutup, kita dapat menggambarkan kemungkinan mengajar teater dengan cara membayangkan lingkaran. Dalam memilih aktivitas drama, guru harus mempertimbangkan kelas yang mereka ajar. Untuk anak kelas rendah, pengalaman drama yang paling cocok adalah drama kreatif/ teater sederhana. Anak-anak di kelas tinggi akan menikmati pentas teater, pembacaan dan penulisan naskah, serta mengadaptasi sastra drama. Tidak masalah dengan bentuk teater yang guru pilih atau bagaimana mereka memutuskan untuk menggunakannya di dalam kelas dan lintas kurikulum, yang penting adalah bahwa guru selalu harus fokus kepada anak-anak. 


\section{DAFTAR PUSTAKA}

Chapman. (1984). Young Playwrigh. Portsmouth: Heinemann

Christie (1990). Dramatic Play: a Context for Meaningfull Enggagment. Boston: Allyn and Bacon.

Cox (1999). Teaching Language Arts. Boston: Allyn and Bacon.

Crombach, L.J. (1980). Education Psychology. New York: Harcourt, Brace and Company.

Endraswara, S. (2003). Membaca, Menulis, Mengajarkan Sastra. Yogyakarta: Kota Kembang.

Galda (1984). Narrative Competence: Play, storytelling and Story Comprehension. Norwood: Ablex.

Harymawan. (1985). Drama Turgi. Bandung: Remaja Rosda Karya.

Hasanudin, W.S. (1995). Drama: Karya dalam Dunia Dimensi. Bandung: Angkasa.

Heathcore (1981) Drama as Education in Mc Caslim (ed.) Children and Drama. New York: Longman.

Heinig (1992) Improvisations with Favorite Tales: Integrating Drama into the Reading/Writing Classroom. Portsmounth: Heinemann.

Hoyt (1992). Many Ways of Knowing, Using Drama, Oral Interaction, and the Visual Art to Enhance Reading Comprehension. Portsmounth: Heinemann.

Munir, B. (2001). Dinamika Kelompok. Universitas Sriwijaya.

Pai, Y. (1991). Cultural Foundation of Education. New York: Maxwell Macmillan. Putnam (1991). Dramatizing Non-fiction with Emerging Readers. Ontario: Pippin.

Ramadhy, S. dan Permadi, D. (2001). Bagaimana Mengembangkan Kecerdasan. Bandung: Sarana Panca Karya Nusa.

San Jose (1988). Story Drama in the Content Area. Boston: Allyn and Bacon

Siks (1983) Drama with Childern. New York: Haper\&Row

Sukmadinata, N.S. (2004). Landasan Psikologis Proses Pendidikan. Bandung: Remaja Rosda Karya.

Supriadi, D. (2000). Kreativitas, Kebudayaan, dan Perkembangan Iptek. Bandung: Alfabeta.

Surya. (1999). Psikologi Perkembangan. Bandung: IKIP Bandung.

Travers, R.M.W. 1990. Essentials of Learning. New York: Macmillan Publishing.

Young \& Vardell (1993) Weaving Reader's Theater and Non-fiction to Curriculum. Williamsport: Brodrat.

\section{BIODATA}

Yunus Abidin adalah dosen pada Universitas Pendidikan Indonesia dpk. UPI Kampus Cibiru Bandung. Penulis menyelesaikan pendidikan pada jenjang magister (S-2) Program Pendidikan Bahasa Sekolah Pascasarjana Universitas Pendidikan Indonesia. 